Foucault's prism, about the same as in Ahrens's prism, and much less than in Nicol's prism.

(2) Only half the prism is made of Iceland spar, a material which is becoming deplorably scarce and expensive (I question if there is in England or elsewhere a piece of spar fit to make a Nicol's prism of $5 \mathrm{~cm}$, aperture). The saving, however, is not so great as it appears, since the spar-prisms $a$ and $b$ are constructed on Wollaston's principle, and involve a certain waste of material.

(3) The combination is not quite free from distortion and chromatic aberration (the latter being due, of course, to irrationality of dispersion; it is practically impossible to achromatise spar with glass), but the imperfection is not serious enough to interfere with its use for many optical purposes, especially as a polariser.

(4) In using it, a diaphragm should be placed in such a position as to limit the entering cone of rays to $28^{\circ}$, since at a greater angle (at any rate, on one side of the field) the ordinary rays are not separated by total reflexion.

Doubtless the prism may be improved upon by better authorilies than myself; but I think that the principle of using a "double-image" prism to increase the divergence of the ordinary and extraordinary rays before one of them is separated by total reflexion is worth attention.

Ahrens's polarising prism is certainly a remarkable one. I do not think that a double-image prism has ever been previously constructed in which the extraordinary ray emerges without deviation, while the other ray is deviated to the extent of very nearly $60^{\circ}$.

Eton College, February 17

\section{THE RESLITS OF THE SCIENTIFIC EXPEDITION TO SODANKYLÄ}

$\mathrm{THE}$ Government of Finland having provided further funds, the Expedition has continued its researches at Sodankylä, in Finnish Lapland, during the year $1883-84$ (NATURE, vol. xxvii. pp. 322 and 389 ). The plan of working this year was chiefly confined to the study of the terrestrial galvanic currents, atmospheric electric currents, and the phenomena of light produced by the apparatus constructed by me for the purpose. The number of daily meteorological and magnetic observations was restricted to three, viz, at $6 \mathrm{a} . \mathrm{m}, 2$ and Io o'clock p.m., Göttingen mean time, but on the Ist and 15 th of each month observations were taken every five minutes, as in the previous year, and on the 8th and and of each month, from 8.30 p.m. till ro. 30 p.m., observations were taken every half minute.

The general meteorological and magnetic observations were continued without interruption until August 22, 1884. In the account of the observations on the luminous phenomena will be included a résumé of the general character of the weather of this year.

The Terrestrial Current. - From the middle of September 1882 the Expedition has observed the terrestrial currents, as well as the magnetic variations. For this purpose two circuits about $5 \mathrm{~km}$. long were placed north-south and cast west. They were connected to platina plates $\mathbf{I}$ decimetre suuare, and burich about $\mathrm{r} \cdot 3 \mathrm{~m}$. below the surface of the ground. The southern and eastern plates were about $0^{\prime} 5 \mathrm{~km}$. from the station. During this year the observations were confined chiefly to the variations of the terrestrial current, hence no attempt was made to separate the electromotive force of the terrestrial current from that which was developed by the contact of the plates with the earth.

In the autumn of 1883 it became necessary to place fresh wires in the circuits, and at the same time the position of the plates was changed, so that cach one was now about $2.5 \mathrm{~km}$. from the station. The old eircuit lying east and west was, however, left undisturbed for some time for the purpose of making comparisons.

It was not until the middle of January that observations of the terrestrial currents were commenced at the auxiliary station at Kultala, $68^{\circ} 29^{\prime} \cdot 5 \mathrm{~N}$. (see Fig. I). Here the circuits for the terrestrial current were placed so that the one lying north-south, $2.9814 \mathrm{~km}$. long, was $3^{\circ}$ west, and the east-west circuit, $4.5663 \mathrm{~km}$. long, lay $69^{\circ}$ north-west. This arrangement was made to permit the plates of the east and west being placed in the River Ivalo, and those lying north-south, in two affluents of this river. At this station attempts were made to eliminate that portion of the electromotive force which arose from the contact of the plates with " earth" (here the water) as well as the polarisation The method employed was as follows:-With a Mascart electrometer, the sensitiveness of which had been exactly measured by a "Daniell" normal element (about 18 divisions of the scale per volt), the electromotive force of all the four plates in the earth was determined. These were then joined in six different ways with a galvanometer, and the deviations noted. A Daniell normal element, furnished with an adjustable resistanceslide, was then placed in the circuit in a contrary direction to the current, and the electromotive force was then reduced till the deviation was $=0$. Thus the electromotive force of the different plates was obtained free of polarisation by means of an electrometer.

To eliminate the electromotive force arising from the contact

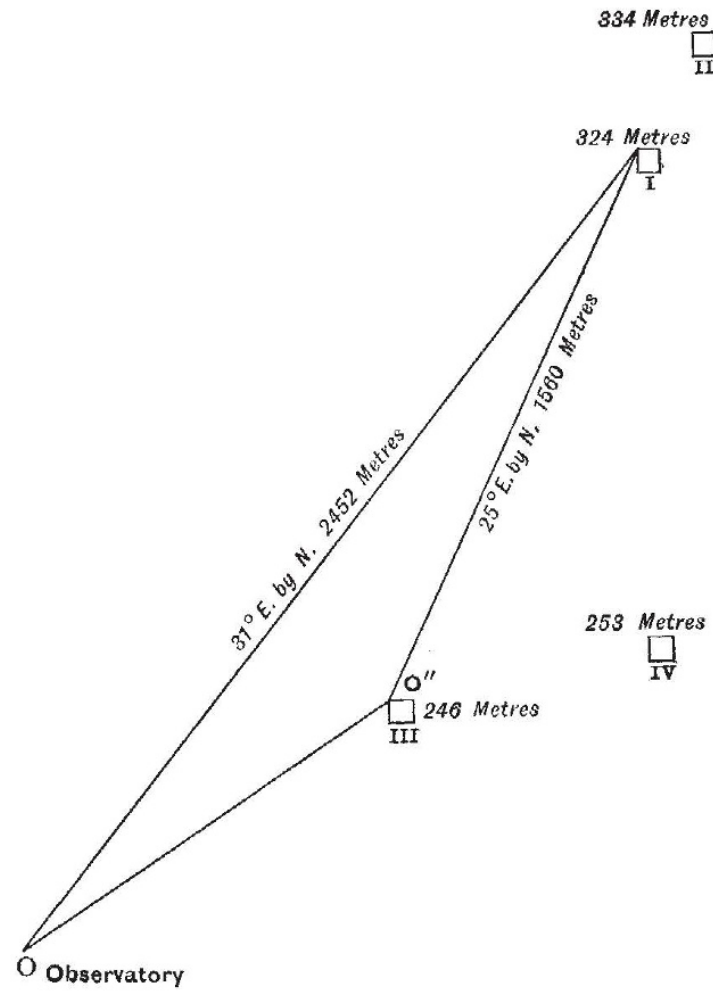

\section{The \\ Kultala Station}

Fic. x,-Plan of the position of the apparatus on the Pietarintunturi Mountains.

of the plates with the water, the latter were taken to the station and sunk in the river close by. They were connected with a wire from the circuits resting on Mascart insulators. Their electromotive force was examined by means of an electrometer, which was discharger each time by a plate of zinc amalgam sunk in the river. This experiment was also made in another manner. All the plates were sunk in a bucket of water resting on Mascart insulators and connected with the earth by a copper wire. The two latter experiments gave very similar results. When the platina plates had been examined in this manner, they were placed in their former positions, after which they werc again examined both by the galvanometer and electrometer. The details of this experiment, as well as those of others, must, however, be reserved for a special memoir. By the ahove-mentioned means results are shown free from any accidental disturbing influences. Some observations, though as 
yet they have not been finally worked out, gave the following results :-

(I) When two galvanometers, as nearly equal as possible, were introduced into the two circuits lying east-west near Sodankylä, and which, as we have said, were moved towards each other so that the old circuit was $2.5 \mathrm{~km}$. further east, the variations of the two galvanometers were nearly identical. This appears clearly from the graphic account of the deviations as they were observed on Oct. I6 from 5 h. $25 \mathrm{~m}$. to $5 \mathrm{~h}, 55 \mathrm{~m}$. p.m. (see Fig. 2). In the abscissa each centimetre represents two minutes, and in the ordinate each millimetre represents a deviation of 20 divisions of the scale, equal to an arc of $20^{\prime}$. The plates of the circuits in question having been sunk to a depth of $\mathbf{I} \cdot 3 \mathrm{~m}$., it is clear that the variations observed arose from changes in the electromotive force of the terrestrial current, and could not have their origin in the changes in the electromotive force arising from the contact of the plates with the earth, for had the latter been the case, the variations could scarcely have shown such extraordinary coincidence. Other similar experiments show, however, that small inaccuracies may occur.

The two curves do not correspond exactly in the intensity of the variations, which arises from the fact that the resistance of the old circuit was greater than that of the new.

While the variations which were greater and more numerous in an east-west direction occurred nearly always at Sodankylä, so that the needles of the galvanometer at that place were rarely at rest, the contrary was the case at Kultala, that is to say, the occasions on which the needles of the galvanometer were in motion were very rare.

As these facts were already observed by me in 1871 and 1882 ,

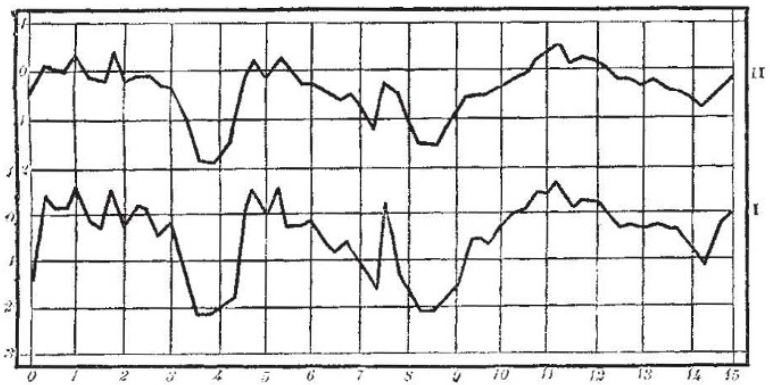

A

FIG. 2. - Curve I. shows the deviations of the galvanometer in the old conductor. Curve II. shows the deviations of the galvanometer in the new conductor. Each centimetre of the abscissa indicates 2 minutes. The observations were made every half minute. Each millimetre of the abscissa indicates $20^{\circ}$ of the scale $=20^{\prime}$ of an arc.

it seems fair to assume that the North Pole of the earth is sur. rounded by a belt in which the terrestrial currents are stronger and more variable than they are north and south of this belt.

The northern limit of this belt seems to be about $68^{\circ} \mathrm{N}$. The position of this belt of terrestrial currents depends probably upon the belt of the aurora borealis.

(3) The magnetic variations and the changes which govern the terrestrial currents follow each other closely. We know that the former depend very much upon the aurora borealis, and that this dependence also influences the latter. However, the laws of this dependence cannot be determined until the materials of the observations have been fully analysed.

The Electric Currents of the Atmosphere studied by means of the Discharging-Apparatus. - Since Franklin and Dalibard proved-about the middle of the last century-by practical experiments that lightning is an electric phenomenon, many attempts have been made to measure the electricity which is always present in the atmosphere. These experiments have become more general since the discovery by Lemonnier, a Frenchman, that electricity was present in the air even without thunderstorms. Numerous methods have bcen invented and employed for examining this electricity, while all had for their object the measurement of the electricity present in a given spot at a given moment. In this manner the atmospheric electricity was carefully observed and registered, and by means of these records it was hoped to arrive at some definite conclusions. Sometimes researches were made to determine the variations of tensions in different directions, particularly the vertical direction. As a general result, but not without exception, these experiments showed that the electrical tension (or potential) increased with the distance from the earth's surface.

The knowledge of the electric charge, or the quantity of electricity present in a given atmospheric space, does not yet convey an exact idea of the electric phenomena which take place therein, but the knowledge of the variations accompanying it in different directions enable us to ascertain the movements of the electricity, or, in other words, the electric currents of the atmosphere. When we know by experience that the generality of effects, and the most important, which produce electricity arise from electric currents, it will easily be understood that the examination of the atmospheric electricity should have for its principal object the visible demonstration of these currents, and an explanation of the laws which regulate them.

The reason why the question has not as yet been studied from this point of view is probably that the air has been regarded as an insulating medium in which only momentary electric discharges occur, and not electric currents.

In the aurora borealis we have a "brilliant " proof of the existence of these currents, but up to the present the cause has always been sought elsewhere.

It is of course understood that a great number of savants have long been of the opinion that the aurora borealis was of electric origin. Having obtained, while with the Swedish Polar Expedition of 1868 , some experience of electric phenomena in Arctic regions, I made some attempts during the expedition of 1871 , near the church of Enare, to see if it was possible with the few means at my disposal to examine this supposed electric current (NATURE, vol. xxvii. pp. 322 and 389). I then succeeded, by means of a small discharging-apparatus, in demonstrating the presence of this current and in producing luminous phenomena, but, owing to certain external difficulties which I could not overcome at that time, these results are uncertain. During the year I882-83 the Expedition at Sodankylä had occasion to make some similar but more extensive experiments, which were crowned with success, as I have previously stated in this journal (vol. xxvii. pp. 322 and 389). An electric current from the air towards the earth was proved to exist. Close to the village of Sodankylä we produced, by means of a large "discharging apparatus" or network of pointed conductors erected upon the summit of Orantunturi (1000 feet in height) a diffuse yellowish light, which, in the spectroscope, showed the ordinary auroral spectrum; and later on a veritable ray of the aurora borealis was produced on the Pietarintunturi Mountain, close to Kultala. On both occasions the electric current was measured.

Important as were the results of these experiments, they were, however, only of a provisional character, because, in carrying them out, difficulties of every description had to be overcome. In all these experiments the apparatus was connected with the earth by a wire leading to a zinc plate immersed in a well. Owing to the contact of the zinc with the water, an electromotive force was produced, and it was therefore probable that the current observed by the galvanometer might have its principal, or perhaps sole, origin in this electromotive force.

The expedition of $1883-84$ was supplied with instruments for overcoming these difficulties as well as others, and has examined as closely as possible the laws which this current obeys.

After the arrival of the expedition at Sodankylä about the middle of September, a provisional apparatus was constructed on the mountain Komattivaara, lying $6 \mathrm{~km}$. from the station, and about 437.5 feet $=129^{\circ} 7 \mathrm{~m}$. high.

A conducting wire, supported by Mascart insulators, was placed from the apparatus on the mountain to the station, where it was joined to a galvanometer, which was connected with the carth by a plate of zinc (amalgam) placed in the neighbouring river. After some preliminary trials with this apparatus, which showed that, in spite of the lowness of the mountain, the atmospheric current could be examined, a "discharging apparatus," or network of pointed conductors, was erected upon a solid wooden structure, and was ready by October 19 . The apparatus consisted of iron wires with welded points $0.5 \mathrm{~m}$. apart. The wire was arranged in a series of squares $1.5 \mathrm{~m}$. from each other, resting upon sulphuric acid insulators attached to poles which were nailed to a wooden frame. The wire with the points covered a surface of 364 square metres. With this apparatus extended experiments were made, chiefly relative to the different kinds of conducting plates to the earth, but space does not permit me to discuss these experiments here. The galvanometer showed a current from the earth towards 
the atmosphere, i.e. from the zinc platc to the "dischargingapparatus."

For the future I will call this direction of the current negative, and the contrary direction from the atmosphere towards the earth the positive. The deviations of the galvanometer werc very variable, and the variations characterised by sudden movements, first in one direction, then in another. With this apparatus observations were made at Sodankylä during last autumn and winter. The deviation of the current was first exactly noted, after which a Leclanché element was introduced into the conductor, first with the positive pole towards the earth, and then towards the mountain. By this process a value was obtained at cach observation of the electromotive force in the circuit of the current. This consisted of two kinds, viz. one arising from the contact of the zinc plate with "earth" (here water), the other from the effect of the electricity in the air upon the apparatus. The first kind varies very little. Regarding the observations at Sodankylä it has becn remarked that they showed, as I have said, a negative current, which however hecame sometimes positive in October and November, and particularly when the aurora borealis was visible.

The daily observations of the atmospheric current were made at Kultala in the same manner as at Sodankylä. During the months of January and February three more "discharging apparatus" were constructed close to this station, and another conducting wire was placed on Mascart insulators. Fig. 2 shows the position of the apparatus, whose elevation was as follows :-

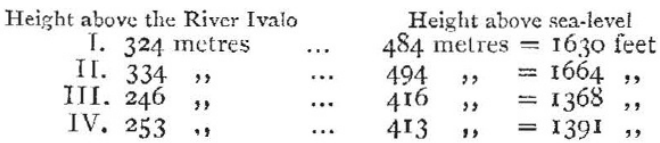

The distance between the station and the Apparatus I. was $3.626 \mathrm{~km}$, and the distance between I. and II. $0.339 \mathrm{~km}$. The following points are also shown by this sketch, viz. :-

$O$ is a small obscrvatory with a chimney; $O^{\prime \prime}$ is the point where the conducting wires of the four apparatus were joined to two wires leading to the station.

With this apparatus numerous experiments were made, chiefly in the month of March, of the results of which the following is a brief résumé :-

(I) If two "discharging-apparatus" are placed at a given elevation and connected with a galvanometer there is no current, i.e. the deviation of the galvanometer equals 0 .

(2) The Apparatus II., connected by a galvanometer to Apparatus I., always gave a positive current, the strength of which varied considerably. The following valucs selected as examples show the electromotive force, expressed in volts, during four days in March :-

$\begin{array}{cccc}\text { March 18 } & \text { March 19 } & \text { March } 20 & \text { March } 21 \\ 0.1171 & 0.1161 & 0.1891 & 0.0530 \\ 0.1714 & 0.1400 & 0.3262 & 0.0530 \\ & & 0.2632 & \\ & & 0.2632 & \end{array}$

These valucs were obtained by introducing a Leclanché clement into the conductor in opposite directions. The electromotive force of this element was determined by comparison with a Daniell normal element. As there was a difference of $10 \mathrm{~m}$. in the height of Apparatus II. and I., it may be noted that the electromotive force varied during the above four days between $0^{\circ} 0326$ and $0^{\circ} 0053$ volts per metre. The above two results show, that the electromotive force of the electric currents of the atmosphere may be stadid with regard to thoir strength, and its variations by means of two "dischargings-apparatus" erected at different elevalions.

When two apparatus at equal elevations give zero, it clearly shows that the electromotive force observed only depends upon the difference in elevation, i.e. that clectricity is clistributed throughout the atmosphere, so that an clectromotive force is produccd, causing a current from the aimosphere towards the earth. The continued study with these four apparatus gave this singular result :-

(3) Close to the carth there is a stratum of positively electrified air, the potential of which is greater than that of the immediately overlying stratum, so that the potential diminishes from the surface of the earth to a minimum, to again increase at bigher altitudes. The Apparatus III. and IV. situated in this stratum gave, combined with I. and II., a negative current, i.e. from the earth to the atmosphere.

This result, so soon arrived at, rendered rather difficult the projected work with the four apparatus, and the difficulty increased still more owing to the fact that the conductive powe: of the air diminishes rapidly nearer the earth. In order to study more minutely this peculiarity, two portable " discharging-appa. ratus "were constructed, consisting of a cross of thin boards, on which were placed several spirals of wires provided with points, the total number of points being thirty. These miniature appatus, which I will call $S_{1}$ and $S_{2}$, were erected near II. upon the most elevated point of Pietarintunturi, $S_{1}$ being $2 \mathrm{~m}$. above the earth, and $S_{z}$ at the top of a pole $9^{\circ} \mathrm{Im}$. high. Both were supported on Mascart insulators, and separately connected with the stations by conducting wires. With this apparatus a current was obtained from $\mathrm{S}_{1}$ and $\mathrm{S}_{2}$, i.e. negative, from the earth to the atmosphere. Creat care was taken against any accidental defect in the conductor, or in the arrangement of the apparatus. The deviation obtained was very small, but quite measurable. The actual experiments with these apparatus were made on March 26 at II p.m., and lasted about three hours. As thesc experiments are of great importance I will describe the method followed.

The night was chosen as the most favourable time, the wind on the mountain being then very slight. The observers, Messrs. Granit and Roos, having telephoned that the experiments could commence, the current was measured by the galvanometer, $\mathrm{S}_{\boldsymbol{1}}$ being then $2 \mathrm{~m}$. and $\mathrm{S}_{2}$ at $9^{\circ} \mathrm{Im}$. above the earth; the dexiation was negative. $\mathrm{S}_{2}$ was then lowered to the same height as $\mathrm{S}_{1}$, when the diviation was $\mathrm{o}$. $\mathrm{S}_{\text {, was }}$ wevated to its former position, and now the deviation was negative as originally. $\mathrm{S}_{1}$ was now attached to two poles $-3 \mathrm{~m}$. high-furnished with Mascart insulators, and then raised by two men to a height of $4 \mathrm{~m}$. The deviation nune became positive.

This proved that the electric density of the stratum of air diminishes up to the point at which the current changed, and that the minimum density lay between a height of $2 \mathrm{~m}$, and $4 \mathrm{~m}$.

It would have been very intercsting to have continued these experiments and further extended them, but this could not be done, as the stay on the mountain became impossible.

I went up on March 25 to examine the apparatus and convince myself that no mistakes had been made, and althongh the temperature was not more than $-12^{\circ} \mathrm{C}$. it was impossible to work except with the back to the wind, for if the face was turned towards it, in a few moments the flesh bccame benumber, and breathing difficult and painful. On the mountain there was nearly always wind, but its strength was less at night.

These experiments with the portable apparatus will be resumed next spring at Sodankylä under the superintendence of $\mathrm{Mr}$. Biese, but as it is very probable that the electric state of the atmosphere will then be totally clifferent, it is impossible to foretell whether they will give the anticipated results.

(4) From the stratum which lies some feet above the earth the electromotive force increases with the differences in height of the "discharging-apparatus." It has not been possible to determine exactly the laws which regulate this incrcase, but it is believed that the electromotive force increases more rapidly than in proportion to the difference in height.

The above results were obtained on clear days. The moisture of the atmosphere affects the resistance of the conductors, and appears also to act upon the electromotive force.

On one of the small apparatus, $S_{1}$, a number of points were furnished with wicks soaked in petroleum; when these were lighted the effect was measured, and it appeared that the resistance diminished a little, but the clectromotive force remained unchanged, Further resulis obtained from the observations must depend on a detailed examination of the materials collected.

Siudy of the Luminous Phenomeno caused by the "DischargingApparatus."-Before passing to a final risumb of the results of these researches, I will refer in general terms to the meteorological character of the year, which are very important in relation to this subject. It is very seldom that the winter in Lapland is so mild as the last one was. There was not much rain or snow, but it snowed nearly every day, so that the days when there was a clear sky can easily be counted. It is only in perfectly clear weather that the luminous electric phenomena are visible, and this only happens when the moonlight is not too brilliant. Consequently therc were very few evenings when the luminous phenomena could be successfully observed. 
Another remarkable circumstance proves that the electric forces worked under abnormal conditions, viz. by the small number of auroræ appearing, which does not amount to one-tenth of the normal number according to the latitude, and except in three cases their intensity was very feeble. The cause thercof is to be found, I believe, in the constantly falling snow and the comparatively high temperature. Even the diffuse luminous phenomena which were seen so often during the winter of I882-83 (see my former report), and which gave the spectral reaction of the aurora borealis, were very rare.

In fact, according to all reports, the characteristics of this winter are quite contrary to the preceding one, which is the more surprising as we are now in a maximum period of auroral manifestations. There have indeed been very few evenings on which the luminous phenomena could be studied, and the best of them have nearly always been accompanied by a full moon. The contributions which the expedition has been able to make to the study of these phenomena are therefore relatively small, but sufficiently important. We know from our former experiments that the "discharging-apparatus" produces a luminosity, sometimes in the form of a cloud-light, sometimes in rays which rise above the apparatus. The diffuse luminosity which always gave the spectral reaction of the aurora was produced very easily. It was aistinctly seen alove the apparatus at Sodankyia, sometimes even with the naked eye, and very often with the spectroscope,

As early as the autumn of $1882 \mathrm{Mr}$. Biese discovered that it was possible to obtain a spectral reaction of the aurora to the southsouth-east of Sodankylä, a few degrees above the horizon, in the direction of the mountain Luostatunturi, while to traces were visible elsewhere. During the autumn of 1883 the same reaction was sometimes obtained from the mountain Komattivaara, although it could not be perceived in the above-mentioned direction. This luminous phenomenon was also very distinctly observed on the following nights, viz.:-

On the evening of November I, when a strong wind from the west had chased away the clouds, an aurora was seen which com. menced with a fairly regular arc in the north-north-west. The arc touched the eastern horizon at about $20^{\circ}$ north of Komattivaara. While the reaction was obtained along the whole length of this arc, it entirely disappeared at this point of $20^{\circ}$ from the horiz on between the foot of the arc and the mountain. Moreover, this was distinctly shown as the slit of the spectroscope was directed towards the discharging-apparatus. On the southern side of the mountain the reaction again disappeared completely. As a general rule, the study of this luminous phenomenon was made at a distance of $5 \mathrm{~km}$., but on two occasions rather closer. On November I2, in spite of the moonlight, moist air, and snow, a distinct reaction was obtained at a distance of $\mathbf{I} \mathrm{km}$. That evening the phenomenon was very brilliant, appearing like a moving luminosity along the whole apparatus, with a diffused radiating fan of light above. It was observed for fifteen minutes.

At Kultala the Iuminous phenomena were generally of greater intensity, but the majority of them could only be seen by means of the spectroscope, chiefly because on the most favourable occasions the moonlight was too bright. In order to obtain another proof of the electric origin of the aurora borealis, the expedition was furnished with a double Holtz machine, which, in spite of its fragile construction, arrived safely at its destination. When this machine was connected with the circuit of Apparatus I., with the positive pole towards the earth, the luminosity was more distinct. This was noticed as early as December $\mathrm{r} 7$ at Sodankyla, when the machine was connected with the conductor from Komattivaara, but the more exhaustive studies were made at Kultala. The observations, which were always made from the house $O$ (sce the sketch), have the following dates, viz. :-1884: January 27, February $3,4,6,7,8,12$, I6, 20, 24. They were made by Mr. Biese and myself, and we have a report of each evening, that of February 3 being written by me, the others by Mr. Biese. We detail below those of February 3 and 7 .

February 3.-Arrived at the Observatory at 6.30. The moon had risen, and shone brightly on the tops of the mountains; no trace of the aurora could be seen either by the naked eye or the spectroscope. At a telephonic signal the Holtz machine was connected with the conductor, the positive pole being placed towards the earth. But in spite of the closest attention no trace of auroral light could be discovered. Presently, however, the moon became covered with a haze (nimbus), and the brightness of its rays diminished by one-half; when this had lasted about half an hour, a luminous phenomenon in the shape of white clouds rose in flames from Apparatus I. This gave the reaction in the spectroscope, and was very distinct, even to the naked eye. At a signal, the machine was again put in motion, and now the flames followed each other every time, giving the reaction in the spectroscope. This reaction had sometimes a certain peculiarity : although the slit of the spectroscope was very straight, the line of the aurora was rather broad, and was followed by a continuous and very distinct spectrum towards F. At eight o'clock the machine was stopped, and the flames became fewer and feebler. At $8.15 \mathrm{p} . \mathrm{m}$. the machine was again put in motion, with the same result as before. Presently a fog covered the summit of the mountain, and the experiments ceased at 8.40 p.m.

February 7.-. The clouds were about 5 C S. (5/10 cirrostratus), hence the reactions could only be obtained as projections upon the bright spectrum of the moon. Now and then a very feeble reaction was obtained towards the north and west, but the Apparatus I. gave none of them. However, when the Holtz machine was put in motion, a very distinct one was obtained, particularly when sparks were emitted. After a Geissler tube had been placed in the conductor of the machine the reaction became still more intense, and was very distinct when the discharge was accompanied by sparks. Never had I obtained so intense a reaction. Mr. Biese again remarked that no absorption-band had been observed near $\mathrm{D}$ in the spectrum of the moon, although its intensity varied considerably. From these data may be inferred :-

(I) That the "discharging-apparatus" produces on certain occasions a diffuse light which gives the spectral reaction of the aurora borealis.

(2) That a Holtz machine placed in motion in the conductor intensifies the phenomenon, if it already exists, and may even produce it under favourable external conditions.

(3) This luminous phenomenon is invisible to the naked eye if the moonlight is very bright, but even then the spectroscope often shows its presence.

After my experience of the power of the "discharging-apparatus" to produce luminous phenomena in the form of rays, I thought the phenomenon would appear easily. The following conditions are however, I have discovered, necessary for this: a clear sky, lo is temperature, and a relatively low barometer. These conditions have been very rare this winter, and when they have been present it was in an imperfect manner. However, the phenomenon was seen twice, viz. on February 27 and March 2 , according to the following reports by Mr. Roos:-

February 27,1884 . - From the point o a feeble auroral arc was observed extending from west to north-north-east, the intensity of which gradually increased. At the same time there appeared in the direction of Pietarintunturi, above the arc but not connected therewith, a sheaf of very intense rays, which moved rapidly westward and disappeared after passing the northern line. Not a single ray was visible in any other part of the sky.

March 2.--Messrs. Granit, Ross, and myself observed from this point an aurora whioh rapidly increased in intensity, and formed a corona as early as 8 o'clock. I immediately went to point III., in order that the luminous phenomena which might appear above the apparatus at Pietarintunturi might be observed from two points simultaneously. About $10.30 \mathrm{I}$ perceived a very intense ray in the direction of Apparatus I., leaning at first a little to the cast, but rising by degrees like a radiating sheaf, with a slight westerly direction. The phenomenon lasted from thirty to forty seconds. On telephoning to Mr. Granit, who remained at point $o$, he replied that no luminosity was visible above the apparatus. Afterwards, and at short intervals, I three times saw a feeble ray in the same direction, but of different aspect. The ray, which was vertical, appeared of equal size and of a pale yellow colour. Although feeble it was very distinct. According to Mr. Granit no rays could be olsserved from point $O$, either above the apparatus or around the mountain for a space of about $15^{\circ}$ on either side, and on this occasion the moonlight was very bright, which, together with the intense aurora, rendered the observation of the luminous phenomena very diffcult, and hesides this, the distance from o to 1 . is $2.45 \mathrm{~km}$., while from III. to I. it is only I. $56 \mathrm{~km}$.

If any doubt remained as to the first observation, i.e. as to whether the rays were above the mountains or not, the second, taken on March 2, is quite conclusive. If Mr. Granit could perceive no rays at point $O$, at a distance giving an angle of $15^{\circ}$ 
at two sides of the mountain, that merely proves that the light was too feeble to penetrate a distance of $2.45 \mathrm{~km}$., though it was visible at $1.56 \mathrm{~km}$. The reflection of the moonlight was also stronger at point o than at III., because on this occasion the moon was nearly north -east.

It is not easy, I confess, to make a résumé of the results arrived at by the researches of the Finnish Expedition to Lapland concerning the electric currents of the earth and the atmosphere, chiefly owing to the circumstance that the materials are not as yet fully analysed, but the following may, however, be accepted as quite certain, as they are based on actual observations:-

The aurora borealis, which has long been a disputed enigma, is the result of an atmospheric electric current.

This auroral current can be measured, and, as a rule, studicd, by the methods employed by the Expedition.

The "discharging-apparatus," or network of pointed conductors, used by the Expedition, has very often produced a diffuse light which gave in the spcctroscope an auroral spectrum. Under very favourable conditions the light appeared in the form of rays above the apparatus.

With a Holtz electric machine the diffuse light may be produced under favourable conditions, and if it exists already it may be considerably intensified by the same means.

For the study of terrestrial electric currents a method has been found which, while avoiding all foreign infuences, permits of the current being measured, both as regards absolute strength and as regards the exact laws which regulate it.

From these experiments it seems that the existence of a belt of terrestrial currents similar to the belt of auroral currents is very probable.

Helsingfors University

SELIM LEMSTRöM

\section{ON THE NATURE OF LICHENS}

I $N$ the Fournal of the Linnean Society for December I2, 1884 (Botany) there appears a review of the " Algo-Lichen Hypothesis," by the Rev. J. M. Crombie, F.L.S., from the strongly conservative point of view of Nylander, on which I desire to make a few remarks as a critical student of Botany at large.

Mr. Crombie cites, as a fatal objection to Schwendener's hypothesis of symbiosis between the lichen proper and the alga forming its gonidia, that in other cases of vegetable parasitism "the hosts usually become speedily exhausted and finally perish, often involving in their death that of the parasite itself ; "whereas here we have "a parasite exceeding in size and number of cells by many hundred times the nourishing plant which it invests." It is now over six years since I sent you, with reference to this very point, a brief note on the subject, which probably escaped Mr. Crombie's notice by its brevity, and of which I reproduce the substance. The essential elements of nutrition of a fungus, so far as we can judge from culture experiments, are as follows:(I) ash constituents; (2) nitrogen in the form of nitrates, nitrites, or ammonia; (3) carbon and hydrosen combined in the form of tartrate, carbhydrate, or fat, \&c. An alga requircs only Nos. I and $\mathbf{z}$, deriving No. 3 by assimilation from the carbon dioxide of the atmosphere and water. The lichen hyphr, aided by excretion of carbon dioxide, can dissolve the ash constituents, No. I, from the substratum, taking them up by the rhizoids; the rain probably brings No. 2 in the form of traces of nitrates; No. 3 can only be formed by assimilation in the algal part orgonidia of the lichen. But, to obtain the carbhydrates, No. 3 , there is no need for the hypha to penetrate the gonidium or to molest its protoplasm, as the algal cells have a cellulose wall, of which the outer layers undergo constant gelification and renewal. Into this it is that, as shown by Bornet "Sur les Gonidies des Lichens," Ann. Sc. Nat. Bot., ser. 5, xvii.) the hyphæ penetrate; and if they only lived on this, once formed, there would be no strain whatever on the resources of the alga. But, even if they stimulate an abnormally rapid cellulose formation, the injury need not necessarily be severe. We see oysters living well, though their shells are burrowed by the sponge Cliona; they produce new layers of shells far faster than when they are sound, but arc otherwise uninjured.

An unlooked-for confirmation of these views is found in Johow's account of the Hymenolichenes (in Pringsheim's ' F a hr bücher, xv., part 2), where, "in consequence of the unusually close and perfect investment of the gonidia" by the hyphr, the gelatinous investment of their cell-wall completely disappears. This is in marked contrast with the usual state of things as figured by Bornet.

De Bary puts the case thus:- "With their growth (of the algæ) the assimilation of carbon dioxide persists in their protoplasm with its chlorophyll, and produces organic carbon compounds utilisable by the fungus. At the same time the rhizoids of the fungus ramify on and in the substratum, and bring the mineral pabulum required. These two processes support and complement one another (Vergleichende Morphologie u. Physio. $\log i e$ d. Pilze, \&c., 1884, p. 425).

It is further noteworthy that, if the growth in size of the gonidia is often favoured by their inclosure in the lichen-thallus, their rapidity of multiplication by division is notably impeded; while spore-formation, \&c., remains in complete abeyance.

$\mathrm{Mr}$. Crombie recalls the absence of algæ in places where lichens abound, e.g. "granitic detritus and boulders towards the summit of lofty mountains." "This follows from the fact that the alga alone cannot there obtain, unassisted, their papulum No. I, the mineral substances or ash constituents. The absence of the fungi alone from these localities simply shows that they cannot live without their algal gonidia.

$\mathrm{Mr}$. Crombie gives as an essential distinction between the hyphæ of lichens and those of fungi the character of their cellwall: "perennial, firm, penetrated by lichenin, thick, imputrible, and insoluble in caustic potash in the former ; caducous, very soft, with thin walls, readily putrifying on maceration, and, on the application of caustic potash, immediately becoming dissolved.'

As regards the thickness and permanence of the walls, it needs hardly to be recalled how much this character varies in different parts of the same fungus, and notably in corresponding organs of different members of the same group of fungi : com pare Polyporus and Boletus, Schisophyllum and Coprinus. As to the presence of lichenin, De Bary states (op. cit., p. Io) that in at least three gelatinous fungi--Hyduum erinateus, Polystigma, and Hysterium macrosporium-the hypha turns blue on the application of aqueous solution of iodine, that is, gives the "lichenin reaction."

$\Lambda \mathrm{s}$ rcgards the alleged solubility of fungus hyph in caustic potash, I am at a loss to understand it, having, like most workers, been in the habit of using this reaction "for clearing" vegetable preparations to demonstrate the presence of parasitic fungus hyphr, which would be impossible if it dissolved them. And I find no account of this solubility of fungal cell-walls in Hof meister's very complete "Lehre von der Pflanzenzelle," or in De Bary's above-cited work.

A misapprehension on the part of the author is to think that the Schwendenerian school have overlooked the "cellular cortical layer" when they speak " as if only two elements enterec into the structure of lichens, viz. hyphre and gonidia." This is duc, so far as it is true, to the general recognition by mycologists that such pseudo-parenchyma as that composing the cellular cortical layer of lichens, of fungus sclerotia, \&c., is only an extreme modification of the hyphe. But, far from being ignored, it is figured and described by Sachs ("Text-Book of Botany," (Ist Engl. ed., Figs. 188, 189, and explanation), who says "The upper and under cortical laycrs [of Sticta] also consist of hyphre, which, however, . . . consist of shorter cells, and are united without interstices, forming a pseudo-parenchyma." Its formation is also described by Bornet (op. cit., p. 97), and 1$)$ Bary writes (op. cit., p. 436): "The hypha-branches forming the cortical layer ('Rindenschicht') are united without interstices, save in certain species of Rocella. They are either recognisable as such, having the lumina of their segment cells evidently elongated and cylindrical, even though shorter than those of the metulla, or else they are formed of short isodiametric rounded prismatic cells, giving the cortex the structure of a pseudo-parenchyma, which is often extremely regular and neat ("sierlich'). . . . The structure of these cortical layers shows great similarity to that of many sclerotia."

In the latter half of the paper Mr. Crombie exposes at length the view that the gonidia originate in the cellules of the hypo. thalline and cortical layers, ${ }^{1}$ and illustrates it by figures. In this no attempt is made to show the part played by the protoplasm in the process, an omission which is an implied confession of the inadequacy of the weapons, optical and technical,

As regards his statement that "specimens illustrating the earlier stage of lichen growth appear to be unknown to the supporters of Schwendene ianism," it is only necessary to revert to Bornet's paper, p. 97. 